\title{
UPAYA PENGURANGAN CEMARAN LOGAM BERAT PADA DAGING KERANG HIJAU (Perna viridis) DENGAN LARUTAN KITOSAN
}

\author{
Jovita Tri Murtini, Hedi Indra Januar dan Sugiyono")
}

\begin{abstract}
ABSTRAK
Telah dilakukan penelitian mengenai upaya pengurangan cemaran logam berat pada daging kerang hijau (Perna viridis) melalui perlakuan perendaman dalam larutan kitosan dengan konsentrasi $0,5 \%, 1 \%$ dan $1,5 \%$ dalam asam asetat $1 \%$ selama 1, 2 dan 3 jam. Parameter yang diukur adalah kadar air, merkuri, arsen dan timbal. Hasil penelitian menunjukkan bahwa perlakuan yang paling banyak menurunkan logam merkuri dalam daging kerang hijau adalah perendaman dalam larutan kitosan 1,5\% selama 3 jam, untuk arsen adalah larutan kitosan 1,5\% selama 2 jam. Untuk penurunan logam timbal adalah perendaman dalam larutan kitosan $1,5 \%$ selama 3 jam.
\end{abstract}
ABSTRACT: Effort to reduce heavy metal contamination on green oyster (Pema viridis) meat with chitosan solution. By: Jovita Tri Murtini, Hedi Indra Januar and Sugiyono

Research to reduce heavy metal contamination on green oyster (Perna viridis) meat was done by dipping the meat in chitosan solution at various concentration, i.e. $0.5 \%, 1 \%$, and $1.5 \%$ in $1 \%$ acetic acid for 1,2, and 3 hours. Parameters measured were moisture content as well as mercury, arsen and lead contained in the oyster meat. Results showed that the highest reducing treatment for mercury, arsen and lead were dipping with $1.5 \%$ chitosan solution for 3 hours, $1.5 \%$ chitosan solution for 2 hours and $1.5 \%$ chitosan solution for 3 hours respectively.

KEYWORDS: heavy metal, contamination, and chitosan

\section{PENDAHULUAN}

Pencemaran logam berat pada perairan merupakan salah satu pencemaran yang dapat membahayakan baik bagi organisme yang ada di dalamnya maupun manusia yang mengkonsumsi organisme yang tercemar. Logam merkuri $(\mathrm{Hg})$ dan timbal $(\mathrm{Pb})$ termasuk logam berat dengan toksisitas tinggi (Hutagalung, 1991), begitu juga arsen (As). Di Kalimantan Tengah di sekitar Sungai Kahayan, penduduk di daerah tersebut menambang emas menggunakan merkuri untuk mengolahnya. Pengolahannya dilakukan langsung di atas rakit. Limbahnya yang langsung dibuang di sungai tersebut akan mengakibatkan tercemarnya air sungai Kahayan yang digunakan untuk kebutuhan hidup bagi sebagian penduduk sekitar sungai tersebut (Ray, 2004). Laporan Nicodemus dalam Sodikin (2003) menyatakan bahwa, berdasarkan penelitian tahun 2002, kadar merkuri air sungai Kahayan sudah $5 \mathrm{ppb}$ yang berarti telah melewati ambang batas yang telah ditentukan (1 ppb), sedangkan pada sedimen sudah mencapai $0,789 \mathrm{ppm}$ yang berarti sudah di atas ambang batas $0,350 \mathrm{ppm}$ Adapun kandungan merkuri dari ikan baung yang hidup di Sungai Kahayan telah mencapai 0,676 ppm, jumlah ini juga sudah melampaui ambang batas untuk konsumsi yaitu $0,5 \mathrm{ppm}$.

Jumlah logam berat yang terakumulasi dalam jaringan tubuh hewan air yang masih aman dikonsumsi oleh manusia ditentukan dalam standar. Kep Ditjen POM No. 03725/B/SKNII/1998 dan WHO (1976) menentukan batas maksimum kandungan logam $\mathrm{Hg}$ pada organisme laut yang boleh dikonsumsi yaitu 0,5 ppm dan untuk logam Pb yaitu 2 ppm (Kep. Ditjen POM No. 03725/B/SK/VII/1989 dan WHO 1989). Timbal dapat meracuni otak, ginjal, alat reproduksi dan jantung. Bagi anak-anak keracunan $\mathrm{Pb}$ dapat menurunkan tingkat kecerdasan. Kandungan $\mathrm{Pb}$ sebesar 1 ppb dalam darah anak-anak dapat menurunkan 1-5 poin tingkat kecerdasan anak (Anon., 1999). Porsepwandi (1998) menyatakan bahwa kerang hijau yang dibudidayakan di Muara Kamal Teluk Jakarta mengandung $\mathrm{Hg}$ dengan rata-rata $3,95 \mathrm{ppb}$

Peneliti pada Pusat Riset Pengolahan Produk dan Sosial Ekonomi Kelautan dan Perikanan 
Angka pencemaran tersebut dari tahun ke tahun akan terus meningkat seiring dengan semakin banyaknya industri yang terdapat di daerah tersebut (Hutagalung, 1994).

Berkaitan dengan hal di atas, maka perlu adanya suatu upaya untuk menurunkan kadar logam $\mathrm{Hg}, \mathrm{Pb}$ dan As pada daging kerang hijau sehingga pengaruh negatif terhadap masyarakat yang mengkonsumsinya dapat dicegah. Irwansyah (1995) menyatakan bahwa salah satu upaya untuk menurunkan kandungan logam berat pada tubuh kerang hijau yaitu dengan merendam daging kerang tersebut dalam larutan pengkhelat logam seperti $\mathrm{Na}_{2} \mathrm{CaEDTA}$ dan kitosan karena zat pengikat logam ini mempunyai kemampuan untuk mengikat ion logam dalam bentuk ikatan kompleks dan menariknya keluar dari jaringan (Linder, 1992). Kitosan ini sangat baik untuk kelasi logam-logam berbahaya misalnya $\mathrm{Cu}, \mathrm{Ni}, \mathrm{Cd}, \mathrm{Mn}, \mathrm{Co}, \mathrm{Pb}, \mathrm{Hg}$ dan Ag dalam rangka meningkatkan detoksifikasi limbah yang berbahaya. Juga telah dikembangkan kemampuan kitosan untuk mengkelasi logam bes yang sangat berguna untuk perjernihan air pada kolam renang dan spa (Sanford, 1989)

Pada penelitian ini dilakukan upaya penurunan kadar logam berat terutama $\mathrm{Hg}, \mathrm{Pb}$ dan $\mathrm{As}$ pada kerang hijau hasil panen dari perairan Muara Dadap dengan menggunakan zat pengkhelat, yaitu larutan kitosan.

\section{BAHAN DAN METODE}

Bahan yang digunakan dalam penelitian ini adalah kerang hijau (Perna viridis) yang diperoleh dari lokasi budidaya di perairan Muara Dadap Jakarta. Bahan lain yang digunakan dalam penelitian ini adalah kitosan sebagai pengkhelat serta bahan kimia lain yang diperlukan untuk analisis. Kitosan dibuat sendiri di laboratorium menggunakan bahan baku kepala udang dengan menggunakan metode Sanford (1989).

Untuk persiapan percobaan, kerang yang akan dianalisis diambil dagingnya dengan cara dibuka dari cangkangnya kemudian ditimbang untuk masingmasing perlakuan. Daging kerang kemudian direndam selama 1, 2 dan 3 jam dalam larutan kitosan dengan konsentrasi $0,5 \%, 1 \%$ dan $1,5 \%$ dalam asam asetat $1 \%$

Parameter yang diamati adalah kadar air dan kadar logam merkuri, arsen dan timbal. Analisis logam Hg, As dan $\mathrm{Pb}$ pada daging kerang hijau dilakukan dengan menggunakan Atomic Absorption Spectrophotometry (AAS) Perkin Elmer. Preparasi contoh menggunakan metode Hutagalung et al. (1997)

Analisis data menggunakan rancangan acak lengkap faktorial dengan 2 faktor dan 3 kali ulangan, dengan membandingkan antar perlakuan yaitu konsentrasi kitosan dan waktu perendaman daging kerang dalam larutan kitosan

\section{Cara Pembuatan Kitosan Dari Kepala Udang}

Kepala udang (dari berbagai jenis udang) diperoleh dari Muara Baru yang merupakan limbah dari pabrik udang. Kepala udang yang masih basah dicuci kemudian dijemur sampai kering, kemudian direndam dalam $\mathrm{NaOH} 3,5 \%$ dengan perbandingan (bahan : $\mathrm{NaOH}) 1: 6$ selama 24 jam (proses deproteinasi). Setelah perendaman kepala udang dicuci dengan air sampai netral, dan direndam kembali dalam $\mathrm{HCl} 1,25 \mathrm{~N}$ $(11,37 \%$ v/v) selama 24 jam pada suhu kamar (proses demineralisasi) dan selanjutnya dicuci dengan air sampai netral. Kepala udang yang sudah ditiriskan direndam kembali dalam NaOH 50\% (proses deasetilasi) selama 48 jam pada suhu kamar kemudian dicuci dengan air sampai netral. Selanjutnya bahan dijemur sampai kering, dan digiling menjadi tepung kitosan. Kitosan yang diperoleh mempunyai derajad deasetilasi sebesar $65,05 \%$ dan dapat larut dalam asam asetat $1 \%$

\section{HASIL DAN BAHASAN}

Hasil analisis kandungan merkuri pada kerang hijau (Perna viridis) dengan berbagai perlakuan perendaman dalam larutan kitosan dapat dilihat pada Tabel 1

Dari hasil analisis ternyata perlakuan konsentrasi kitosan dan lama perendaman berpengaruh sangat nyata ( $p \quad 0,00$ ) terhadap penurunan kadar merkuri dalam daging kerang. Perlakuan perendaman daging kerang dalam larutan kitosan, yang dapat menurunkan kadar merkuri terbesar adalah dari kerang yang direndam dalam larutan kitosan pada konsentrasi $1,5 \%$ selama 3 jam yakni sebesar $94,89 \%(15,23$ ppb dalam berat kering). Hal ini kemungkinan akibat terjadinya ikatan antara merkuri dengan gugus fungsional amin $\left(\mathrm{NH}_{2}\right)$ yang ada pada kitosan. Hal yang sama telah digambarkan kemungkinan adanya adanya ikatan antara $\mathrm{Cu}$ dan kitosan yang akan membentuk ikatan kompleks (Rinaudo \& Domard, 1989). Larutan kitosan ini dapat mengikat logamlogam terutama logam divalen.

Daging kerang yang diperlakukan dengan larutan kitosan mempunyai kandungan arsen yang lebih rendah dibandingkan dengan yang tidak diperiakukan (kontrol). Walaupun demikian, dari hasil analisis ternyata antar perlakuan konsentrasi larutan kitosan tidak berpengaruh terhadap penurunan kadar arsen (As) dalam daging kerang hijau $(p \approx 0,43)$. Perlakuan waktu perendaman juga tidak berpengaruh nyata terhadap penurunan kandungan arsen dalam daging 
Tabel 1. Kadar merkuri, arsen, dan timbal pada kerang hijau (Perna viridis) setelah perlakuan Table 1. Mercury, arsen and lead content of green oyster (Perna viridis) after treatment

\begin{tabular}{|c|c|c|c|c|c|}
\hline \multirow{2}{*}{$\begin{array}{c}\text { Konsentrasi } \\
\text { kitosan/ } \\
\text { Concentration } \\
\text { of chitosan }\end{array}$} & \multirow{2}{*}{$\begin{array}{l}\text { Waktu } \\
\text { perendaman/ } \\
\text { Time of } \\
\text { dipping }\end{array}$} & \multirow{2}{*}{$\begin{array}{c}\text { Airl } \\
\text { Moisture } \\
\text { (\%) }\end{array}$} & \multicolumn{3}{|c|}{ Logam berat/Heavy metal (ppb, DB) } \\
\hline & & & $\mathrm{Hg}$ & As & $\mathbf{P b}$ \\
\hline \multirow{3}{*}{$0.5 \%$} & 1 jam/hour & $83.06 \pm 0.04$ & $11.10 \pm 0$ & $8.56+0.24$ & $1.30 \pm 0.05$ \\
\hline & 2 jam/hour & $82.75 \pm 1.27$ & $10.20 \pm 0.06$ & $3.53+0.24$ & $4.64 \pm 0.01$ \\
\hline & $3 \mathrm{jam} /$ hour & $83.36 \pm 2.79$ & $2.70 \pm 0.02$ & $11.30 \pm 0.27$ & $0.96 \pm 0.01$ \\
\hline \multirow{3}{*}{$1.0 \%$} & 1 jam/hour & $83.07 \pm 2.98$ & $11.52 \pm 0.06$ & $6.44 \pm 0.11$ & $0.83 \pm 0.01$ \\
\hline & 2 jam/hour & $81.05 \pm 1.69$ & $9.18 \pm 0.09$ & $5.62 \pm 0.57$ & $0.84 \pm 0.01$ \\
\hline & 3 jam/hour & $82.78 \pm 0.60$ & $1.86 \pm 0.09$ & $11.61 \pm 0.02$ & $0.93 \pm 0.01$ \\
\hline \multirow{3}{*}{$1.5 \%$} & 1 jam/hour & $83.57 \pm 1.22$ & $4.99 \pm 0.15$ & $6.21 \pm 0.38$ & $0.73 \pm 0.01$ \\
\hline & $2 \mathrm{jam} /$ hour & $81.57 \pm 0.37$ & $3.74 \pm 0.22$ & $4.72 \pm 0.10$ & $0.92 \pm 0.02$ \\
\hline & 3 jam/hour & $81.47 \pm 0.58$ & $0.81 \pm 0.04$ & $6.36 \pm 0.96$ & $0.54 \pm 0.01$ \\
\hline \multicolumn{2}{|c|}{$\begin{array}{c}\text { Segar tanpa perlakuan/ } \\
\text { no treatment }\end{array}$} & $79.49 \pm 0.46$ & $16.04 \pm 0.26$ & $22.04 \pm 0.55$ & $15.31 \pm 0.87$ \\
\hline
\end{tabular}

kerang hijau $(p \approx 0,27)$. Dari hasil analisis ternyata perlakuan konsentrasi larutan kitosan berpengaruh sangat nyata $(p \approx 0,00)$ terhadap penurunan kadar $\mathrm{Pb}$ dalam daging kerang. Begitu juga waktu perendaman daging kerang dalam larutan kitosan berpengaruh $(p \approx 0,03)$ pada penurunan kadar $\mathrm{Pb}$ dalam daging kerang hijau. Tetapi waktu perendaman yang berpengaruh $(p \approx 0,05)$ adalah antara perendaman 2 jam dan 3 jam. Apabila dibandingkan dengan kandungan $\mathrm{Pb}$ dalam daging kerang hijau yang tidak mengalami perlakuan maka perlakuan perendaman daging kerang hijau dalam larutan kitosan tersebut dapat menurunkan kandungan logam $\mathrm{Pb}$ sebesar $96,48 \%$ (14,8 ppb dalam berat kering). Dari Tabel 1 dapat dilihat bahwa perlakuan pada daging kerang hijau dengan cara perendaman dalam larutan kitosan dapat menurunkan kadar $\mathrm{Pb}$. Perlakuan yang paling banyak menurunkan logam timbal dalam daging kerang hijau adalah perendaman kitosan $1,5 \%$ selama $3 \mathrm{jam}$. Hal ini menunjukkan bahwa kitosan juga mempunyai sifat mengikat logam timbal dalam jaringan daging kerang hijau. Namun demikian, efektivitas penggunaan kitosan ini belum teruji dengan baik karena tidak adanya pembanding yang digunakan. Pada penelitian selanjutnya perlu digunakan pembanding sehingga dapat diketahui apakah pengurangan kandungan logam berat tersebut adalah akibat perlakuan dengan kitosan atau karena pengaruh pelarutnya

\section{KESIMPULAN}

Perlakuan yang paling banyak menurunkan $\mathrm{Hg}$ dalam daging kerang hijau adalah perendaman kitosan $1,5 \%$ selama 3 jam, sedangkan untuk As adalah perendaman kitosan $1,5 \%$ selama 2 jam, dan untuk $\mathrm{Pb}$ adalah perendaman kitosan 1,5\% selama 3 jam. Perlakuan yang direkomendasikan untuk penurunan logam berat pada kerang hijau adalah dengan merendamnya dalam larutan kitosan $1,5 \%$ selama 3 jam.

\section{DAFTAR PUSTAKA}

Anonymous. 1999. Heavy metal and health. http:// www.wri.org/wr-98-99/metals2.htm. World Resources 1998-99. $7 \mathrm{pp}$.

Direktorat Jenderal Pengawasan Obat dan Makanan, 1989. Standardisasi Pengawasan Perikanan dan Hasil Perikanan. Direktorat Jenderal Pengawasan Obat dan Makanan, Departemen Kesehatan, Jakarta. p. $1.1-4.6$

Hutagalung, H.P., 1991. Pencemaran Laut oleh Logam Berat. Status Pencemaran Laut di Indonesia dan Teknik Pemantauannya. Puslitbang Oseanologi (LIPI), Jakarta. p. 45- 59 
Hutagalung, H.P.,1994. Kandungan logam berat dalam sedimen di perairan Teluk Jakarta. Prosiding Seminar Pemantauan Pencemaran Laut Jakarta 07-09 Februari 1994. Puslitbang Osenologi (LIPI), Jakarta. p. 1-6

Hutagalung, H.P., Permana, D.S. dan Riyono, S.H. 1997. Metode Analisis Air Laut, Sedimen dan Biota. Buku 2. Pusat Penelitian dan Pengembangan Oseanologi, LIPI, Jakarta. $182 \mathrm{pp}$

Irwansyah, 1995. Efektifitas Khitin Sebagai Bahan Pengabsorpsi Residu Logam Berat Raksa (Hg) pada Kerang Hijau (Mytilus viridis L.). Skripsi, Fakultas perikanan dan Kelautan, IPB, Bogor. 65 pp

Linder, M.C., 1992. Biokimia Nutrisi dan Metabolisme Dengan Pemakaian Secara Klinis. UI-Press, Jakarta. $781 \mathrm{pp}$.

Rinaudo, M. and Domard, A. 1989. Solution properties of chitosan. In Braek, G.S., Anthonsen, T. and Sandford,
P. (eds.). Chitin and Chitosan. Elsevier Applied Science. London-New York. 71 pp

Porsepwandi, W. 1998. Pengaruh pH Larulan Perendaman Terhadap Penurunan Kandungan $\mathrm{Hg}$ dan Mutu Kerang Hijau (Mytilus viridis Linn.). Skripsi, Fakultas Perikanan dan Kelautan, IPB, Bogor. 42 pp. Ray, 2004. Warga Terancam Keracunan Merkuri di Tepi Sungai Kahayan. Kompas, Kamis 8 April 2004, 29 pp.

Sanford, P.A., 1989. Chitosan : Commercial uses and potential applications. In Braek, G.S., Anthonsen, T. and Sandford, P. (eds.). Chitin and Chitosan. Elsevier Applied Science. London-New York. 51 pp.

Sodikin, A., 2003 Awas Bencana Merkuri Mengintai Kalimantan. Kompas, Selasa 15 Juli 2003. 31 pp.

WHO. 1976. Mercury, Environmental Health Criteria I. WHO, Geneva. $130 \mathrm{pp}$.

WHO. 1989. Lead, Environmental Health Criteria 85 WHO, Geneva. $106 \mathrm{pp}$. 